\title{
Surgical treatment of septal perforation due to button battery with allograft dermal matrix
}

\section{Saat piline bağlı gelişen septal perforasyonun allogreft dermal matrix ile cerrahi tedavisi}

\author{
Haşmet Yazıcı, ${ }^{1}$ Erhan Arslan, ${ }^{2}$ Sedat Doğan, ${ }^{3}$ Cem Bayraktar $^{3}$ \\ ${ }^{1}$ Department of Otolaryngology, Medical Faculty of Balikesir University, Balikesir, Turkey \\ ${ }^{2}$ Department of Otolaryngology, Kazan State Hospital, Ankara, Turkey \\ ${ }^{3}$ Department of Otolaryngology, Medical Faculty of Adryaman University, Adryaman, Turkey
}

\begin{abstract}
A four-year-old girl was admitted to our clinic with complaint of left sided foul smelling nasal discharge. In the examination, a button battery and $1 \times 1 \mathrm{~cm}$ septal perforation were detected in left nasal cavity. In this article, we report our experience of successful intranasal endoscopic repair of nasal septal perforation by using interpositional human dermal allograft (SureDerm) with the review of literature.

Keywords: Allograft dermal matrix; button battery; septal perforation.
\end{abstract}

Nasal foreign bodies are commonly seen in childhood and usually present with symptoms of unilateral foulsmelling nasal discharge or may persist asymptomatically for a long time depending on the foreign body. Button batteries cause chemical reactions in the nose and may lead to serious infection, necrosis and nasal septal perforation. ${ }^{[1]}$ The repair of septal perforations is generally unsatisfactory. However, early diagnosis and appropriate surgical technique increase the probability of success. We present the case of a young girl with nasal septal perforation caused by a button battery that was surgically repaired using allograft dermal matrix.

\section{CASE REPORT}

A four-year-old girl was referred to our ear nose and throat (ENT) clinic from the child protection agency

\section{$\ddot{O} Z$}

Dört yaşında bir kız çocuk burnun sol tarafından kötü kokulu akıntı yakınması ile kliniğimize başvurdu. Muayenede sol burun boşluğunda bir saat pili ve $1 \times 1 \mathrm{~cm}$ boyutunda septal perforasyon saptandı. Bu yazıda interpozisyonel insan dermal allogrefti (SureDerm) kullanılarak burun içi endoskopik yolla başarıly onarılan burun septal perforasyonu deneyimimiz literatür taraması eşliğinde sunuldu.

Anahtar sözcükler: Allograft dermal matriks; saat pili; septal perforasyon.

with the compliant of left-sided foul smelling nasal discharge for one week. A foreign body in the left nasal passage, purulent secretion, and crusts were observed on physical examination and extracted under general anesthesia. The nasal cavity was edematous with burnt mucosa from the chemical reaction caused by the button battery (Figure 1). A 1x1 cm nasal septal perforation was seen after crust removal. Antibiotics, anti-inflammatory and nasal irrigation therapy were administered for one week before septal perforation repair was performed under general anesthesia. Intraoperative hemostasis was obtained using 1:100000 epinephrine and 2\% lidocaine solution injections. After 15 minutes, the perforation edges were dissected with endoscopic guidance. A Killian incision was performed and mucoperichondrial flaps were elevated on both sides to place the allograft dermal 
matrix material for closure of perforation. The $2 \times 2 \mathrm{~cm}$ allograft dermal matrix was interposed between both mucoperichondria and sutured with 4.0 Vicryl to the nasal septal mucosa. Bilateral silastic sheets were placed for six weeks. The septal perforation was completely closed on the second month of follow-up (Figure 2).

\section{DISCUSSION}

Nasal foreign bodies are commonly encountered in emergency departments. Although more frequently seen in the pediatric population, foreign bodies in the nasal cavity may also be seen in older patients with mental retardation or psychiatric. ${ }^{[2]}$ Nasal foreign bodies comprise $25-35 \%$ of all foreign bodies in ENT practice $^{[3,4]}$ The most common symptom of nasal foreign bodies is unilateral foul-smelling nasal discharge. ${ }^{[5]}$ However the incidence of asymptomatic nasal foreign bodies is not so rare and they may be diagnosed late. Early diagnosis may be increased by rigorous anamnesis and examination with the aid of endoscopic and radiographic examinations.

Different types of foreign bodies seen in the nose include beads, buttons, toy parts, paper, food and button batteries. ${ }^{[6,7]}$ Button batteries are among the most dangerous and emergent foreign bodies in the nasal cavity due to their chemical reaction. Their cytotoxic, destructive effect on nasal mucosa occurs within two hours and may cause perforation in any part of the head and neck region. ${ }^{[8]}$ The process of nasal mucosal damage in nasal foreign bodies was explained by Kavanagh and Litovitz. ${ }^{[9]}$ The inflammatory reaction starts with spontaneous electrolyte leakage and liquefaction necrosis. Progression of the necrosis results in cumulative tissue damage, corrosive effect, and

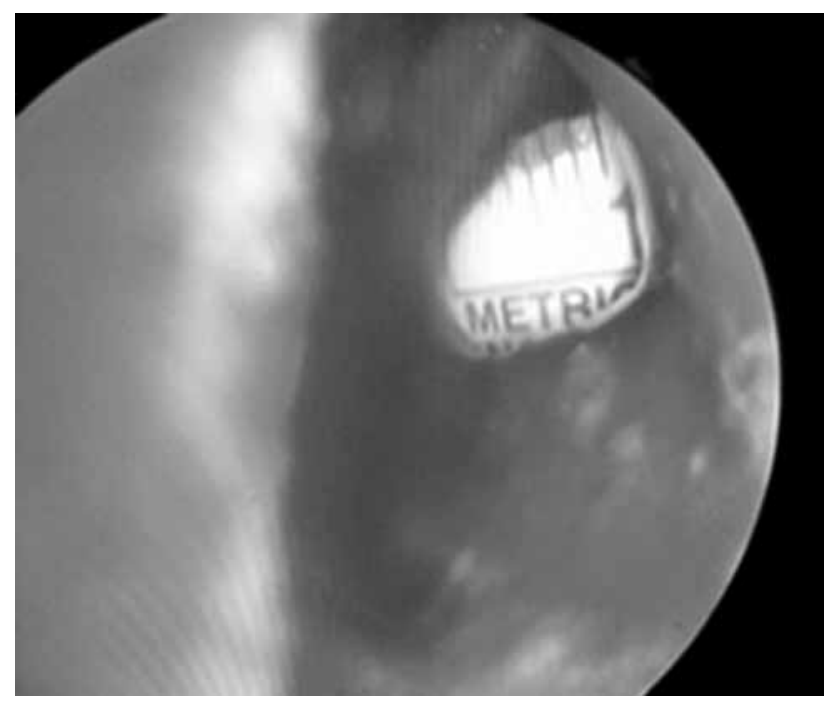

Figure 1. Preoperative view of septal perforation. pressure necrosis from the impacted foreign body. Based on these pathologic processes, the importance of early removal of the foreign body may decrease morbidities by decreasing the inflammatory reactions and related chemical corrosive effects. In the absence of immediate treatment, these bodies in the nose result in necrosis of nasal mucosa, scarring, septal perforation, synechiae and nasal cavity stenosis. ${ }^{[10]}$

Surgical septal perforation repair includes various techniques such as advancement of mucosal flaps, lateral nasal wall sliding flaps, and autografts using temporal fascia or allograft dermal matrix by endoscopic endonasal and open external approaches. ${ }^{[11,12]}$ However, surgical nasal septal perforation repair is usually less than satisfactory especially in large perforations. In this case we used SureDerm ${ }^{\mathrm{TM}}$ (Hans Biomed Corp., Seoul, Korea), an allograft dermal matrix containing collagen, elastin and proteoglycan to repair the septal perforation. We opted not to use mucosal advancement or lateral nasal sliding flaps due to the inflammatory and nonsterile nasal cavity setting. Additionally vascular supply problems may occur less with allograft dermal matrix compared to sliding flaps and autografts. Waiting for normalization of nasal mucosa before performing mucosal flaps is time-consuming and may decrease success of the operation due to the increased risk of fibrosis.

The septal perforation repairing surgery should aim to obtain normal nasal physiology. ${ }^{[11]}$ Septal perforations

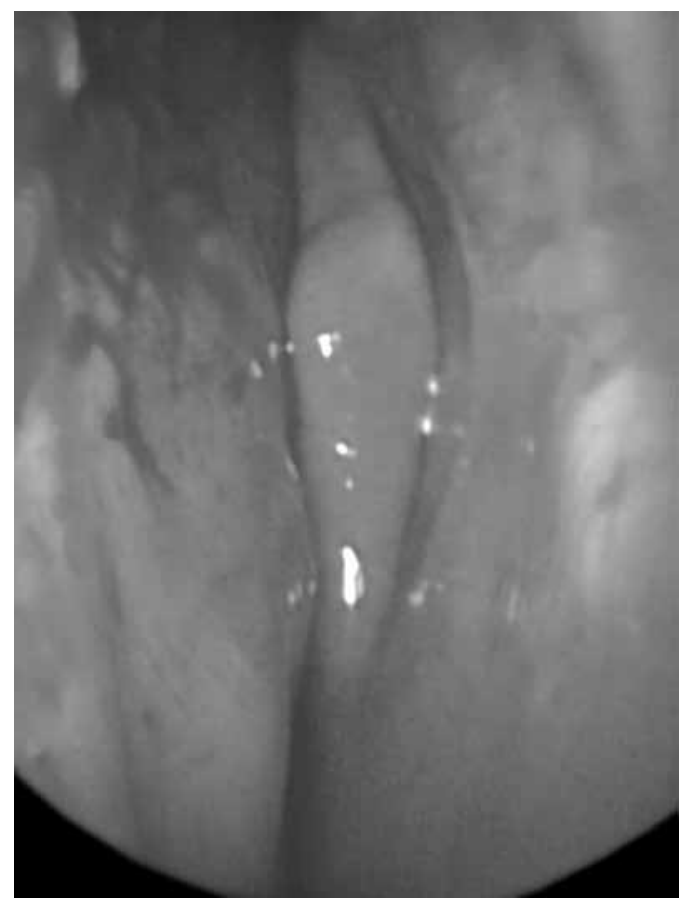

Figure 2. Postoperative view of nasal septum at the second month follow-up. 
cause turbulent airflow in the nasal cavity and result in crust formation and nasal obstruction. To obtain normal airflow, the material used for repairing perforations should be rigid, be vascularized in order to merge with nasal mucosa and should not activate host defense reactions. Grafts with insufficient vascular supply and merging capacity with perforation edges act as a barrier against closure of the perforation especially when fibrotic tissues have not been excised enough. In addition, the mucosal migration over the interpositioning graft material that is critical for success of the operation would be difficult when vascularization of the graft is low or absent. Placing the graft without any covering material may also cause various problems such as infection and vascular supply problems. SureDerm ${ }^{\mathrm{TM}}$ has a strict, acellular and non-host defense trigging structure and it fulfills the optimal properties of a graft material. Collagen and elastic fiber content of SureDerm ${ }^{\mathrm{TM}}$ allows vascularization of the graft, facilitates merging with nasal mucosa and eliminates the necessity of a covering tissue. SureDerm ${ }^{\mathrm{TM}}$ also facilitates the recovery of normal airflow due to its structure. For these reasons, long survival of the graft and early restoration of normal nasal physiology may be achieved by SureDerm ${ }^{\mathrm{TM}}$.

To the best of our knowledge, only one clinical trial has been reported using SureDerm ${ }^{\mathrm{TM}}$ for septal perforation repair. Lee et al. ${ }^{[13]}$ reported $90 \%$ success with SureDerm ${ }^{\mathrm{TM}}$ application in septal perforation surgery. They reported only one incomplete closure and this case was caused by a button battery. The mean perforation size was $5 \mathrm{~mm}$ but the duration of perforation was not mentioned in their study. Our patient's perforation size was $1 \mathrm{x} 1 \mathrm{~cm}$ and was diagnosed at the first week of the onset of symptoms. We obtained complete closure in our patient and we think that the early diagnosis and treatment process contributed to our success.

In conclusion, SureDerm ${ }^{\mathrm{TM}}$ may be an appropriate graft material for septal perforation surgery.

\section{Declaration of conflicting interests}

The authors declared no conflicts of interest with respect to the authorship and/or publication of this article.

\section{Funding}

The authors received no financial support for the research and/or authorship of this article.

\section{REFERENCES}

1. Yeh B, Roberson JR. Nasal magnetic foreign body: a sticky topic. J Emerg Med 2012;43:319-21.

2. Baluyot ST. Foreign bodies in the nasal cavity. In: Paparella MM, Shumrick DA, editors. Otolaryngology. Philadelphia: W.B. Saunders; 1980. p. 2009-16.

3. Endican S, Garap JP, Dubey SP. Ear, nose and throat foreign bodies in Melanesian children: an analysis of 1037 cases. Int J Pediatr Otorhinolaryngol 2006;70:1539-45.

4. Ngo A, Ng KC, Sim TP. Otorhinolaryngeal foreign bodies in children presenting to the emergency department. Singapore Med J 2005;46:172-8.

5. Srinivas Moorthy PN, Srivalli M, Rau GV, Prasanth C. Study on clinical presentation of ear and nose foreign bodies. Indian J Otolaryngol Head Neck Surg 2012;64:31-5.

6. Chan TC, Ufberg J, Harrigan RA, Vilke GM. Nasal foreign body removal. J Emerg Med 2004;26:441-5.

7. Kalan A, Tariq M. Foreign bodies in the nasal cavities: a comprehensive review of the aetiology, diagnostic pointers, and therapeutic measures. Postgrad Med J 2000;76:484-7.

8. Chevin JC, Attik G, Dika H, Duval RE, Bottin $\mathrm{MC}$, Raspiller MF, et al. Button battery induced cell damage: A pathophysiological study. Electrochemistry Communications 2008;10:1756-60.

9. Kavanagh KT, Litovitz T. Miniature battery foreign bodies in auditory and nasal cavities. JAMA 1986;255:1470-2.

10. Bhatia R, Singhal SK, Dass A. Button cell causing septal perforation in a child. Clinical rhinology: An international Journal 2010;3:161-3.

11. Islam A, Felek S, Celik H, Arslan N, Can IH, Oğuz H. Repair of nasal septal perforation with different intranasal flap techniques and their outcomes. [Article in Turkish] Kulak Burun Bogaz Ihtis Derg 2009;19:232-8.

12. Turgut S, Dere H, Özcan İ, Özdem C Eksternal rinoplasti yaklaşımı kullanarak septum perforasyonu onarımı. KBB ve Baş Boyun Cerrahisi Dergisi 1995;3:59-64.

13. Lee KC, Lee NH, Ban JH, Jin SM. Surgical treatment using an allograft dermal matrix for nasal septal perforation. Yonsei Med J 2008;49:244-8. 